\title{
The Purpose of Education: Australian and Slovenian perspectives in Education for Sustainability
}

\author{
Phil Smith, Majda Naji
}

Envigogika 8 (4) - Inspiration

Published: 31. 12. 2013

DOI: http://dx.doi.org/10.14712/18023061.407

\begin{abstract}
:
Clarity of purpose in education drives sensible decisions about curriculum, policy, infrastructure, funding and training. This article proposes that sustainability must be central to the purpose of education in the $21^{\text {st }}$ century, and it looks at two examples of how this is being incorporated into schools in Slovenia and Australia. Cross-curriculum approaches lie at the heart of effective integration in both countries: these connect current school subjects, and they help form the ethos of the whole school. The National Education Institute of Slovenia (NEIS) has developed a cross-curriculum concept by emphasizing Education for Sustainable Development as a model called the ESD School. The structure of an ESD School can be adapted for all national curriculums. In Australia, a new National Curriculum for schools requires sustainability to be integrated into all curriculum areas. Schools are taking this up in ways suitable to culture, leadership and other contextual variations. It is the opinion of the authors that schools must have a sustainability purpose and a solid model for achievement if our students are to learn the skills and values for a sustainable and safe future.
\end{abstract}

\section{Keywords:}

purpose of education, sustainability education, cross-curriculum, integration, ESD school model 


\section{Education: On Purpose}

What should be the purpose of education? Ask anyone, including education ministers, and you'll get a different answer to the question of purpose. Adam Burk reminded us again of this in his 2011 TED conversations - his global survey on the TED portal revealed that there were as many different views about the purpose of education as there were respondents (Burk, 2011).

School systems must, of course, maintain a focus on quality teaching, student outcomes and school improvement, but not at the expense of asking, "To what end?" Systems tend to look inwards. They must look out and encourage conversations about the overall direction and purpose of education.

Thomas Nielsen (University of Canberra) points out that, in Australia, education policy debate centres on literacy and numeracy. He says our education model is founded on individualism, narrow academic achievement and a rationalistic-economic view of life. The constricted purpose of merely developing intellect or contributing to the economy distorts human existence. "Education must be about developing the whole person. About helping them to identify their passion and strengths so they can go on and make a positive difference in the world," argues Chris Smyth (personal communication 2012), Schools Leadership Consultant in the Wagga Wagga Catholic Education diocese of New South Wales, Australia.

Yes, education must develop the whole person and help students pursue their passion and realise their potential. But none of this happens in a vacuum. Education must also help students understand the context in which they are operating and in which they have choices. Indeed, the context helps shape personal expression of passion and talent.

What's the context in which schools are currently operating?

The 21st century faces challenges such as global warming, ecosystem losses, water deficits, conflict, diminished soils, disease and risk of pandemics, environmental refugees, unequal distribution of wealth over-population, intolerance of human diversity and terrorism.

In 'The impossible and the necessary: Challenges for educators. Are you ready for this?', Michael Barber, a leader in education reform, says children are our sustainable future. He links the outside world with the inside world of classrooms and says being welleducated needs not just a focus on knowledge, thinking and leadership, but on the ethical underpinnings that drive education...

"Your schools...need to prepare every young person to rise to challenges...and exploit the emerging opportunities - to thrive in vast, diverse cities, share the planet with other living things, preserve the wilderness, generate economic growth without waste, resolve conflicts peacefully and deploy wisdom and judgement at moments of crisis....these are matters...on which the quality of life, and perhaps life on Earth itself, ultimately depends... each school [is] a microcosm of the better society you might become; each teacher an example of the better humanity to which you aspire."

We believe there are two prime purposes of education: to help students learn to live in the world outside the classroom; and to help students develop the knowledge, skills and values to be able to improve that world. This is about understanding the context in which 
they are learning, and inspiring and helping them to make it better. This is a sustainability agenda!

We believe sustainability must become the guiding purpose for education. By sustainability, we mean healthy people living in healthy communities on a healthy planet. Schools must move beyond the notion of integrating sustainability into curricula and practice in schools. Education systems everywhere need to see their overarching purpose as integrating education into sustainability. Decisions over policy, training, curricula and implementation must come to be filtered through such questions as, 'To what extent will this decision contribute to a sustainable society?' and, 'To what ends are our efforts directed?' Systems must also keep asking, 'Why those ends?'

Further, we need to consider the measures by which we assess achievement in schools and of schools. In the March/April 2012 issue of the Orion Magazine, Derrick Jensen, American author, environmental activist and one of Utne Reader's "50 Visionaries Who Are Changing Your World," put it this way (Jensen, 2012):

"...the fact remains that if we judge my work, or anyone's work, by the most important standard of all, and in fact the only standard that really matters, which is the health of the planet, my work (and everyone else's) is a complete failure. Because my work hasn't stopped the murder. Nor has anyone else's. We haven't even slowed it down. It's embarrassing to have to explain why this is the only standard that really matters, but at this point embarrassment is the least of our problems. The health of the planet is the only standard that really matters because without a living planet nothing else is important, because nothing else exists."

We believe that governments must weigh up what's important - not from ideological or short-term, narrow economic points of view, but from a futures point of view. They need to ask, 'What's happening out there in the world now? What do our students need in order to thrive in that world? What knowledge, skills, values, and learning experiences do they need to be able to make the world better?'

We believe that students need the skills, values and knowledge to act interdependently. They must learn to ask good questions and question received wisdoms and assumptions at all levels. They must think critically as well as creatively, and be able to envisage a more equitable, just and sustainable world. They need to be agile thinkers adept at coping with and shaping change - or preventing unwanted change. They must learn to operate with a broader sense of self, distinguish ideology from conviction, and have the courage to act out of a sense of right that is founded on not harming others or the environment even in the face of opposition or apathy.

Teachers will need to help students connect the dots - to recognize the relationships between self and others, actions and impacts, problems and solutions, ideas and disciplines. Education systems must help teachers in their roles as visionaries, collaborators, designers, adaptors, leaders, researchers, facilitators, and role models for sustainability.

Schools alone cannot be the solution to every problem from broken economies to too-few Olympic gold medals. But schools can develop young people capable of solving the problems. And education systems can be clear that sustainability imperatives are not going away. Education must integrate public and private purposes and reflect the best a society can know of its broader, longer-term needs rather than its short-term political or economic needs. 
It is our view that the purpose of education must be personal, communal, global, and survival-oriented. Education systems must help students learn to live morally, creatively and productively within the context of striving for sustainability. Good teaching will always remain vital. But the focus must be on building minds prepared to think and bodies prepared to act for sustainability.

\section{Example: Australia - Engadine High School}

In Australia, schools are taking on the challenge of embedding sustainability into school life and teaching, as required by the new Australian Curriculum (ACARA, 2011). Engadine High School, a comprehensive high school in the southern part of Sydney, provides perhaps one of the best examples with their A World Worth Living In (AWWLI) program. AWWLI was a sustainability education program created in 2012 for all students in Year 9 (approximately 15 years old). It involves students in defining and solving real world sustainability problems using skills learnt from across the curriculum. This project-based approach is linked to the curriculum and teaching practice. Teachers engage with sustainability through their teaching programs and act as mentors in the project. They are neither passive observers nor simply the deliverers of content. They work with students in ways that link understanding to real world contexts and solutions. They are the co-learners and facilitators of rapidly evolving fields of understanding.

AWWLI asks students to work on real world problems - first defining them and then looking for pragmatic and plausible solutions. Topics in 2012 and 2013 have included:

- Is a world sustainable without democracy?

- How bullying is affecting our world with use of new technologies?

- How can clean energy provide a more sustainable world?

- What are some actions Australia can take to increase primary education in east Timor?

In the early part of the school year, students take part in workshops to help them grasp deeper understandings of sustainability and the tools necessary for effective research: primary data collection, organising and analysing data, presentation skills, ICT applications, time management and report writing. In the second half of the year, students work in their groups for approximately half a day each week. These groups are comprised of about 6 students and one teacher-mentor. The teacher's role is to advise and guide the students in identifying their problem, researching background information, exploring solutions and preparing findings and solutions.

Groups must deliver a persuasive presentation to a panel of teacher-mentors; work is assessed against set criteria. Throughout the program, students keep a process diary; this documents their progress and helps students reflect upon their learning. Student work is also celebrated in a range of ways including public acknowledgement, displays and other promotions.

The AWWLI project has been incorporated into the school's long-term planning. As well, the school is building a shadehouse, a garden and a 2 hectare bush learning area. School vision and policies have become geared towards reducing impact. Conversations about purpose of education take place in staff meetings.

We find the leaders at EHS to be inspiring and forward-thinking; the leadership processes nurture creativity and leadership in staff and students. 
Engadine High School has a Student Sustainability Council which meets regularly with the Student Representative Council and Prefects. Such involvement raises the profile of sustainability and signals to all the importance that the school community places on learning and practice for a better world. A number of students were supported to attend a one-day Sustainability Leadership course linked to the National Training Framework. And a busload of students from Years 7 - 11 students participated in a Seed 2 Tree program run by HotRock, a sustainability NGO.

Deputy Principal, Paul Owens said in a conversation at the beginning of 2013, "Our vision is not only to develop within our students a deep understanding of sustainability but also to have them become the solutions to the many sustainability problems that face Twenty First Century communities."

The school's approach includes support for teachers. Whole-staff professional development sessions have been conducted, and a sustainability education professional learning program by the same name as the Year 9 project was developed and registered with the NSW Institute of Teachers. This professional development program helped teachers meet their professional requirements with the Institute and was based on the new Australian Standards.

\section{Example: Slovenia - Slovenian ESD School Model}

The key question or dilemma which EU experts face in the field of sustainable education is the implementation of themes and goals of Education for Sustainable Development (ESD) within the national educational policy of individual countries. This also includes the development of curriculum, permanent teacher training and education as well as guaranteeing the quality of education (QCA, 2007). School practice has proven that the extensive project work that is being done in the field of sustainable education in EU countries - for instance within Comenius projects SEED and SUPPORT- is being included in the formal school curriculum but with some difficulty and challenges (SEED Final report 2005, Report from the final conference in the EU Life Long Learning network SUPPORT, 2010)

We believe that on of the most effective method of implementing ESD in the national school scheme includes the cross-curriculum dimensions that enable relevant teaching environments with the help of rational connections between the current school subjects (e.g. Barnes, 2008). Although cross-curricular themes are not a statutory part of the National curricula in most of EU countries, schools find ESD useful in designing and planning their wider curriculum (FNBE, 2004). Cross-curricular themes should not be considered in isolation: there are links (for example) between global issues and sustainable development (Hicks and Holden, 2007).

Having regard to the ET 2010 - a detailed work programme on the follow-up of the objectives of education and training systems in Europe (EU Council, 2002) and ET 2020 - EU Council conclusions on a strategic framework for European cooperation in education and training (EU Council, 2009), Slovenia as a member of the EU, has highlighted the key role of ESD in its national education policies. Slovenia's ESD program "Smernice vzgoje in izobraževanja za trajnostni razvoj od predšolske vzgoje do douniverzitetnega izobraževanja" (Ministrstvo za šolstvo in šport, 2007) plays an important role in national lifelong learning strategies and also can be used as a tool to enhance quality at all levels of education and training. 
ESD in Slovenia has been implemented at each level of pre-university education, taking into account their specific context. Kindergartens can start ESD by fostering basic values, attitudes and knowledge in children. At primary and secondary schools, ESD can focus on the development of key competences. In vocational schools, ESD can be focused on developing more specific skills and the competences needed within various occupations (Ministrstvo za šolstvo in šport, 2007). A whole-school approach (Barnes, 2008) which was used as a basis of Slovenian sustainability program, required the presence of all the stakeholders in ESD: school leaders, teachers, pupils, the school board, administrative and supportive staff, parents, NGOs, the local community and business.

The National Education Institute Slovenia (NEIS) has always had a significant role in the shaping of the Slovenian education system at the pre-university level. NEIS has a visible role in the processes of implementing and monitoring ESD in Slovenian pedagogical practice. Together with schools and kindergartens it has developed methods for the successful transfer of ESD into national education system. The Institute is also strengthening its activities in the international framework as it desires to assert itself at the world level as a reputable professional institution in the area of ESD. This means systematically integrating sustainability and global dimensions into national teaching program and linking Slovenian schools with schools in the EU and beyond.

At a conference Becoming a Global Citizen in Espoo, Finland, 2011, The National Education Institute of Slovenia (NEIS) has introduced the cross-curriculum concept by emphasizing ESD as a model, called the GE (Global Education) School Model (Naji, 2011) - here termed the ESD School Model.

Before we start by introducing the model, we need to ask three questions (Naji, 2011):

1. What are ESD schools trying to achieve?

2. How will the ESD schools organize learning?

3. How well are ESD schools achieving their aims?

The Slovenian ESD School Model has three basic elements, like every classic house: roof, rooms on each floor and foundations. The ESD School roof is formed and supported by clearly set national ESD goals and the personal goals of children (FNBE, 2004; Naji, 2011). The rooms on each floor include school practice as a whole, planned and personal learning experience.

We believe that solid foundations of an ESD School make learning and teaching more effective, give helpful feedback for the learner and other stakeholders, help identify clear targets for improvement and maximise pupils' progress. On the first floor of an ESD School, the statutory expectations of society in the field of sociology and natural science are realized through current school subjects. The second floor includes cross-curriculum dimensions that enable connections between school subjects, advance the development of personal, learning and mental skills of students, thus forming the complete ethos of an ESD School. The third floor is dedicated to teachers who use a variety of inclusive teaching strategies and approaches to build skills and the capacity to make sensible personal choices. The fourth floor includes learning process components like learning hours, different locations of classes in and outside the school, important events across the world and within a local society, thus enabling the students, and an authentic and relevant learning environment. 
When the ESD School determines its priority tasks that are in accordance with the state's national goals and the personal goals of children, it can begin forming and implementing the curriculum as a complete and planned ESD learning and teaching experience. We have to be aware of the fact that an ESD School is formed by school experts and that our students live in this house. Therefore we should build them a school, where they will feel accepted and safe, where they will_enjoy in-learning and make a positive contribution to sustainable society.

More time should be given to the core room of ESD School, where school practice evolves and where the goals and themes of ESD are realized. School subjects with their hundred years of tradition and structure are moving in the fields of knowledge, which are upgraded by cross-curriculum dimensions, among which ESD takes one of the main roles. Cross-curriculum themes can enrich and give meaning to the curriculum experience of young people, thus involving it to in their lifestyle and the way of thinking (Hicks and Holden, 2007).

The proposed structure of an ESD School is appropriate for all national environments. The architecture of an ESD School, especially its core, is mostly influenced by the structural ideology of curriculum - the target, process or content, curriculum ideologies that are oriented toward children, knowledge or society, and mostly the cultural environment, in which an ESD School operates. We propose that the teachers from individual countries prepare their national ESD School Model by considering its basic elements.

\section{References:}

- Acara, (2011). The Australian Curriculum. www.australiancurriculum.edu.au/CrossCurriculumPrioritie: Australian Curriculum, Assessment and Reporting Authority. Retrieved from http://www.australiancurriculum.edu.au/CrossCurriculumPrioritie

- Barber, M. (2009). The impossible and the necessary: Challenges for educators. Are you ready for this?. Melbourne: CSE.

- Barnes, J. (2008). Cross-Curricular Learning. London: Sage Publication.

- Burk, A. (2011). TED Conversations. . Retrieved from http://www.ted.com/conversations/7491/in_your_opinion_what_should_t.html

- School, E. H. . A World Worth Living. www.ehs.nsw.edu.au/en/curriculum/a-worldworth-living-i: Engadine High School. Retrieved from http://www.ehs.nsw.edu.au/en/curriculum/a-world-worth-living-in

- Council, E. U. (2002). Detailed work programme on the follow-up of the objectives of education and training systems in Europe (ET 2010). EU Council. Official Journal C 142/01 of 14.06.2002.,

- Council, E. U. (2009). Conclusions of 12 May 2009 on a strategic framework for European cooperation in education and training (ET 2020). EU Council. Official Journal C 119 of 28.5.2009, 12, 28-5.

- Fnbe, (2004). National Core Curriculum. Helsinki: FNBE - Finnish National Board of Education. 
- Hicks, D., \& Holden, C. (2007). Teaching the Global Dimension. London [England] ; Routledge, 2007: Oxord, UK: Routledge.

- HotRock . Retrieved from http://www.thehotrock.org.au

- Jensen, D. (2012). Loaded Words. Orion Magazine. March/April, 2012, Retrieved from http://www.orionmagazine.org/index.php/articles/article/6698

- Smernice vzgoje in izobraževanja za trajnostni razvoj od predšolske vzgoje do douniverzitetnega izobraževanja. Republika Slovenija. July 2007. (2007). : Ministrstvo za šolstvo in šport.

- Naji, M. (2011) Slovenian Global School Model. In Proceedings of the International Symposium on Competencies of Global Citizens. Helsinki: FNBE.

- Nielsen, T. (2013). Out from the cave: Have we lost the purpose of education. . Retrieved from http://theconversation.com/out-from-the-cave-have-we-lost-thepurpose-of-education-12374

- Qca, (2007). Developing the Global Dimension in the Curriculum. London: QCA Qualification and Curriculum Authority.

\section{Phil Smith}

email: rephilled@hotmail.com

educator, writer, walker, cross-country skier

Director, KnowHands Education Consultancy

NSW Facilitator, HotRock

Lecturer, University of Western Sydney

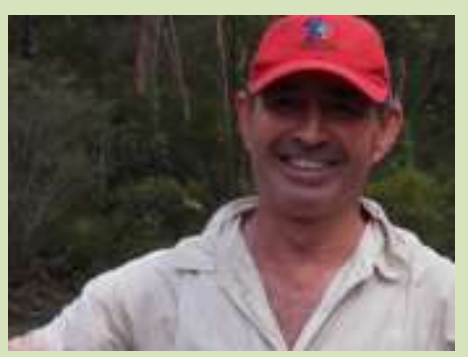

Immediate Past President, Australian Association for Environmental Education

Phil has had fun working in environmental education and advocacy for over 30 years in Australia and overseas - in schools, universities, government agencies and communities. His local, national and international experience includes community campaigning, professional development in sustainability education for teachers and lecturers, strategic program development, evaluation, writing and facilitation.

\section{Dr Majda Naji}

\section{email: majdanaji@mfdps.si}

\section{Assistant Research for ESD and Global Education}

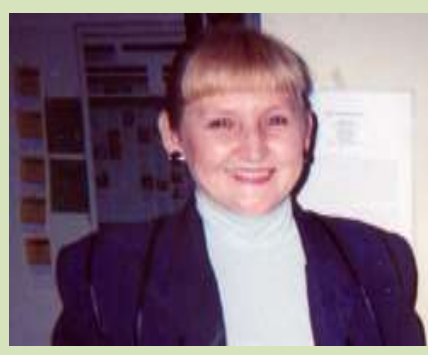

International School for Social and Business Studies (ISSBS), Celje, Slovenia.

Dr Majda Naji is founder of Journal Developing Global Dimension in the Curriculum at National Education Institute Slovenia (NEIS). Majda Naji was a member of Comenius projects SEED, SUPPORT and CoDeS, member of National group for Global Education, Slovenian representative in UNECE and national coordinator for ENSI. 